\title{
Fundamental Truths
}

\author{
Rahila Gupta* \\ *Correspondence: (rahilagupta@googlemail.com)
}

This poem was written in late 1989 for a fundraising event for the then newly set up group Women Against Fundamentalism. It refers to the WAF demonstration in support of Salman Rushdie's right to write, where the WAF women were abused both by the Asian men marching against Rushdie and the National Front counter-demonstration. WAF had to rely on police protection against both threats.

I heard the word fundamentalism first When a Jehovah's witness bit the dust Obscurantist rubbish, my auntie cussed Oh my, I was impressed.

Then it surfaced here and there, When abortion rights were in the air, When that Greek Christ ${ }^{1}$ his sins had bared, I was born again.

Sodom and Gomorrah are still alive, Ranted the Christians setting cinemas alight, 'Man' had strayed from the narrow and tight I said, Hey, what fun!

(C) Copyright: The Authors. This article is issued under the terms of the Creative Commons Attribution NonCommercial Share Alike License, which permits use and redistribution of the work provided that the original author and source are credited, the work is not used for commercial purposes and that any derivative works are made available under the same license terms.
Then this guy Rushdie wrote this book, For this, I hear, a cool million he took Anyway he has a right to cock a snook Good luck to him.

Khomeini rose from the dead, his coffin tumbled When Mohammed asked why Rushdie's words still rumbled Inspiring Bradford Muslims to see who had bungled Why Rushdie nor his book were dead.

The British liberals and the NF rushed to denounce their savage might The British state upheld freedom of speech and civil rights having just buried the Gibraltar killings ${ }^{2}$ and Peter Wright ${ }^{3}$ Such unions are made in heaven. 
The boil of racism erupting in pus

Sadly has silenced many of us

We make a small anti-fundamentalist thrust

and get lumped with the racist lot.

What can we do about those young Asian lads

Using anti-Rushdie marches to fight police squads

We picket a march, marooned, fighting both - Glad,

Yet our loyalties feel confused.

The threat of violence sets up Rushdie's safe houses

Eclipsing the daily violence that women's self-esteem arouses

The stranglehold of religion douses

Our very existence.

We must stand up and fight

Keeping both enemies in sight

Giving voice to women's rights

We have no other choice

Let us not forget what fundamentalism has done

When Hindus kill Muslims and think they have won

When Palestinian stones are scattered with Israeli guns

And the British state squashes the IRA

Ogden Nash made this comment

What is cold to the finger is chilling to the fundament. 
Rahila Gupta is a freelance journalist and writer. Her work has appeared in The Guardian and New Humanist among other papers and magazines. Her books include Enslaved: The New British Slavery; From Homebreakers to Jailbreakers: Southall Black Sisters;

Provoked; and 'Don't Wake Me: The Ballad of Nihal Armstrong (Playdead Press, 2013). She is co-authoring a book with Beatrix Campbell with the title Why Doesn't Patriarchy Die?

\footnotetext{
${ }^{1}$ A cinema in Paris was burnt down by Christian fundamentalists in 1988 for showing the controversial film The Last Temptation of Christ based on a novel by Nikos Kazantzakis and directed by Martin Scorsese

2 Three unarmed members of the Provisional IRA were killed by the SAS (Special Air Service) in Gibraltar in 1988 what was widely seen as extra-judicial killings

${ }^{3}$ Margaret Thatcher unsuccessfully attempted to ban the publication of Spycatcher, a book by former MI5 operative Peter Wright, on the grounds that it was a breach of the Official Secrets Act
}

To cite this article:

Gupta, R. (2016). Fundamental Truths. Feminist Dissent, (1), 64-66. Retrieved from:

http://journals.warwick.ac.uk/index.php/feministdissent/article/view/10 